\title{
Ditransitive and Dative Constructions in English and Thai Languages
}

\author{
ANONGNAD PETCHPRASERT \\ Department of Curriculum and Instruction, \\ Faculty of Education, \\ Ramkhamhaeng University, Thailand \\ anongnad07@hotmail.com
}

\begin{abstract}
This article presents predominant views of the English and Thai ditransitive and dative sentence structures that take verbs to have two major meanings based on schemata: a caused possession and a caused motion. The main purpose of the study was to investigate the associations between verbs and their event schemata, the syntactic and semantic realizations available to the ditransitive and dative sentence structures, and the associations between the parallel structures of the sentences across the languages. The participants of the study were pre-service teachers majoring in English at a university in Thailand. The study was conducted in the 2020 academic year. The analyses demonstrated inference patterns and verb arguments in the double object construction across English and Thai. The results of the study also identified the syntactic and semantic similarities and differences with an account of variant choices that provided insightful explanations of the data in the crosslinguistic realm. Implications for educators revolve around individual differences and other related variables that might yield various results. The findings also suggest the multidimensionality of research into the crosslinguistic analyses of double object construction and linguistic devices.
\end{abstract}

Keywords: ditransitive; dative; sentence structure; English; Thai

\section{INTRODUCTION}

It has been known for a long time that the double object construction (DOC) in syntactic structures is saliently similar or different in some languages, such as English and Thai. The double object construction is known as a construction in which a verb takes two noun phrase (NP) objects as its complements which can be seen in the ditransitive or dative sentence structures (O'Grady, 1998). As many linguists have recently become interested in comparative studies of the double object construction between L1 and L2, it is very important to grasp the associations between two NP objects in sentence structures.

In general, an English ditransitive verb takes a subject, a direct object, and an indirect object with a partially lexical entry. According to this view, a simple ditransitive such as John gave Mary a book derived from an underlying form in which a verb requires the presence of two objects. The primary object is Mary (the recipient of an action), whereas the second object is a book (a patient or an entity), affected by an action (Larson, 1988).

Compared to English, a ditransitive structure in Thai is also associated with the meaning of transference in which the recipient and the patient are affected by an action (Timyam, 2015). The following sentences illustrate this characteristic.

$\begin{array}{llll}\text { จอห์น } & \text { ให้ } & \text { หนังสือ } & \text { แมรี่ } \\ \text { jan } & \text { hây } & \text { năyšnu } & \text { merî } \\ \text { John } & \text { gave } & \text { book } & \text { Mary } \\ \text { 'John gave Mary a book.' } & & \end{array}$


An English dative structure commonly consists of four components: a subject, a transitive verb, a direct object, and an indirect object. The direct object is placed after a verb, whereas the indirect object refers to an object marked by an element indicating 'direction toward' which is in the form of the preposition to (O'Grady, 1998).

Compared to English, a Thai dative structure consists of a subject, a transitive verb, a direct object, and an indirect object (Timyam, 2015). The order of the two objects is associated with the patient 'หนังสือ' [nănsǔu] or 'book' and the recipient named 'แมรี่' [merî] or Mary.

$\begin{array}{lllll}\text { จอห์น } & \text { ให้ } & \text { หนังสือ } & \text { แก่ } & \text { แมรี่ } \\ \text { j̆an } & \text { hây } & \text { năysǔm } & \text { kæææ } & \text { merî } \\ \text { John } & \text { gave } & \text { book } & \text { to } & \text { Mary }\end{array}$

After reviewing the sentences (1-2), the ditransitive and dative structures in Thai are similar or different to those in English at a certain degree, since the structures in English are also marked by the different order of the two objects (the recipient and the patient). Besides, the ditransitive and dative structures in English and Thai describe events of transference, showing options for expressing their arguments jointly referred to the dative alternation.

As the current study aimed to investigate the participants' syntactic and semantic realizations in the ditransitive and dative sentence structures in English and Thai, it would provide significant implications for L2 writing pedagogy and research. Pedagogically, determining the pre-service teachers' abilities to apply L1 and L2 syntactic structures in their English writing would help L2 writing teachers gain better understanding that might be useful for teaching and learning design. Theoretically, the findings will contribute to the growing body of research on the syntactic variations between English and Thai as they inform researchers on how the knowledge of the double object construction should be considered when collecting, analyzing, and interpreting data along with other relevant factors. The following section presents the literature review on English and Thai double object constructions that will be used as a theoretical framework for the present study. Related studies in the field are also presented.

\section{LITERATURE REVIEW}

In general, English and Thai have ditansitive and dative structures, which are often called double object construction (DOC) and indirect object construction (IOC). The two constructions can sometimes be used side by side with no difference in meanings apart from L1 syntactic background.

A variety of ditransitive and dative structures across languages, such as English and Thai has received considerable attention in a crosslinguistic literature for decades (Goldberg, 1995; Hovav \& Levin, 2008; Timyam, 2015). Haspelmath (2015) has pointed to a construction with a verb expressing transference of an entity (T) from an agent (A) to a recipient (R), such as Tim gave Emma a box which is associated with the alignment of the coding of the two object arguments, pushing researchers to explore ways to account for linguistic variation within a restricted theory of linguistic structures.

Hovav and Levin (2008) propose alternative perspectives of the English double object construction, which takes verbs to have two meanings and relates each meaning with a syntactically schematic realization. The first meaning is a caused possession schema which is realized by the double object variant, representing a recipient functioned as an animate entity capable of possession as in (3a-c). 
A. Caused possession schema: ' $\mathrm{x}$ cause $\mathrm{y}$ to have $\mathrm{z}$ '

(3) a. Thomas gave Alice a birthday card.

b. Allisa sent Mary a package.

c. John threw Larry the ball.

Hovav and Levin (2008) identify the second meaning is a caused motion schema which is realized by the to variant, representing a spatial goal that is associated with the position of the patient (4a-c).

B. Caused motion schema: ' $\mathrm{x}$ cause $\mathrm{z}$ to be at $\mathrm{y}$ '

(4) a. Thomas gave a birthday card to Alice.

b. Allisa sent a package to Mary.

c. John threw the ball to Larry.

In line with Jackendoff (1990), and Hovav and Levin (2008), action verbs can be varied in their associations with different meanings or those proposed event schemata. Specifically, the verbs such as give, hand, and lend have only a caused possession schema, while the verbs such as throw, send, and mail have both caused motion and caused possession schemata. Then, crosslinguistic differences might be anticipated in the syntactic realization of the event schemata.

The present study, partially in line with Levin's theoretical framework (2008), focused on the crosslinguistic manifestations of the event schema-argument realization associated with the structural variation of the ditransitive and dative constructions using data from English and Thai sentences. The paper, then, has two goals associated with the two parts of the event schemata distributed in the ditransitive and dative sentence structures as expected across the two languages. Specifically, the distinctions amongst the verbs correlated with event schemata were held in English and Thai. In addition, the findings of the present study show that the actual argument realizations attested in English and Thai for each syntactic structure are not exactly the same because the syntactic and semantic resources of these languages vary. The next section presents the associations of verbs and structures with event schemata as well as verb parallels across the targeted languages.

\section{THE ASSOCIATIONS OF VERBS AND STRUCTURES WITH EVENT SCHEMATA}

The present study was built upon the notion that the caused motion and caused possession meanings represent distinct event schema. The event types distinctively represent causative events, relating possession and motion. Both events also involve an agent and theme arguments, the $x$ and $z$ arguments (Larson, 1988, p. 381). The figure 1 shows a three-place relation $(x, y, z)$ that present arguments for verbs such as give. The significant feature between them is presented in a semantic role of the $y$ arguments $(a-b)$. 

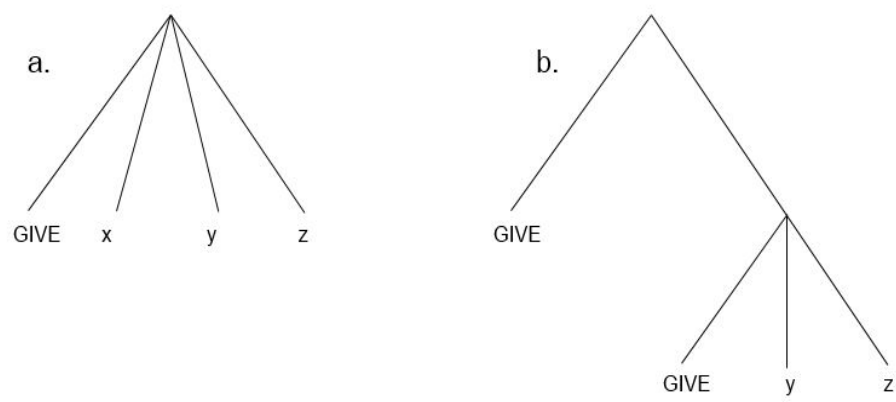

FIGURE 1. An agent and theme arguments

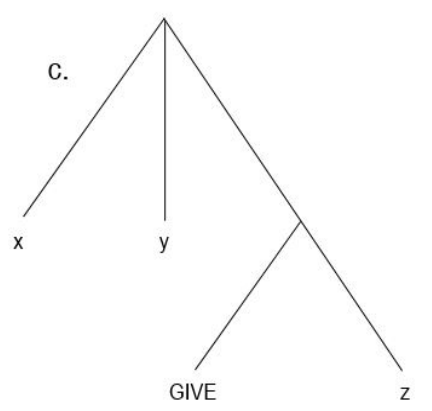

As Levin (2008) suggests, the associations with verb roots are taken into account to analyse those two event schemata: a caused possession schema and a caused motion schema. She also classifies three classes of verbs that are utilized to examine the crosslinguistic manifestations of the argument realization.

a. give-type verbs: give, hand, lend, loan, rent, sell, etc. including verbs of future having: allocate, allow, bequeath, forward, grant, offer, promise, etc.

b. send-type verbs: mail, send, ship, etc.

c. throw-type verbs: fling, flip, kick, slap, shoot, throw, toss, etc.

Goldberg (1995) and Levin (2008) state that the give-type verbs correspond to the caused possession and they do not lexicalize the caused motion even though an object is affected by a movement. This could be that it is possible to give the object without manipulating it. For example, the verbs, such as rent and lend, they represent the limit of time to possess as well as specifying a component of an event.

The verbs in the send type are associated with the motion which is also called the caused motion schema. These verbs may be integrated into an event schema through an active relation affected by the caused possession. In many languages, the send-type verbs are correlated with the caused possession schema (Levin, 2008).

The throw-type verbs are associated with an activity event, describing an event in which an entity instantly affected by a force of a recipient (Jackendoff, 1990). The verb throw involves the force that a recipient moves which is corresponded to the movement of an instrument and manner.

TABLE 1 . The summary of the three-type verbs

\begin{tabular}{cc}
\hline Type of Verb & Type of Event Schema \\
\hline give-type verbs & caused possession only \\
send-type verbs & caused motion, caused possession \\
throw-type verbs & activity, caused motion, caused possession \\
\hline
\end{tabular}

Note: Levin, B. (2008, p.6). Dative verbs: a crosslinguistic perspective.

Overall, the three types of verbs are used to identify the relations between the caused possession schema and the caused motion schema (see Table 1). The following section reviews the verb parallels across languages in the contexts of English and Thai sentence structures. 


\section{VERB PARALLELS ACROSS LANGUAGES}

This research looks at the consequences of the verb parallels in English and Thai languages for understanding the counterparts of ditransitive and dative sentence structures based on the schema-argument realization. The factors that were used to investigate the argument realization of the two structures include: 1) the possible associations of verbs with certain event schemata, 2) the syntactic realizations available to these event schemata, and 3) the nature of verb meanings in English and Thai.

Several studies compared the ditransitive and dative structures with two main reasons: 1) the positions of direct object (Haspelmath, 2015; O'Grady, 1998) and 2) the meaning of transference of an object or information from one entity to another (Goldberg, 1995; Timyam, 2015).

DITRANSITIVE STRUCTURES

As of English, the common structures of the double object construction are shown in $5 \mathrm{a}$ (without a dative marker) and $5 \mathrm{~b}$ (with 'to' as a dative marker).

a. Tim gave Emma a box.

b. Tim gave a box to Emma.

The underlying ditransitive structure is associated with the semantic roles of the two direct objects, meaning the primary object is the recipient of an action or the direct object 1 (DO1), which is a person who receives or benefits from some kind of action. The secondary object is the patient or the direct object 2 (DO2), which is affected by an action.

$$
\text { a. I sent [DO1Emma] [DO2a letter]. }
$$

Regarding the semantic roles, Larson (1988) states that the two direct objects are marked by the two main characteristics which are explained and illustrated below.

Firstly, they cannot be reversed as it violates the order restriction, resulting ungrammatical sentences $(7 b)$.

(7) a. James lent me a few dollars.

*b. James lent a few dollars me.

Secondly, with some verbs, the recipient object may be omitted when its reference is obvious and retrievable in the context. The omissions of the objects are: 1) the omission of the recipient object (8a), and 2) the omission of the patient object (8b).

(8) a. My mother cooked (us) a huge dinner.

b. The teacher is teaching his students (English).

As previously stated, only one of the objects, either the recipient or the patient, can be omitted from a sentence. It may be grammatically correct; however, it may semantically violate the sentence (9a).

(9) *a. Jim bought his sister.

b. Jim bought his sister a coat. 
Compared to English, a Thai ditransitive structure is also associated with the meaning of transference, involving two subclasses of verbs (Timyam \& Bergen, 2010). The two subclasses of Thai ditransitive verbs are:

1) verbs of inherent acts of giving (10) such as 'ให้' [hây] or 'give,' 'คืน' [kh世un] or 'return,' and 'แจก' [cæ⿱æk] or 'distribute.'

\begin{tabular}{|c|c|c|}
\hline สมชาย & แจก & หนังสือ \\
\hline Sǒmchaay & cæ̇æk & năysǔu \\
\hline Somchaay & distribute & book \\
\hline
\end{tabular}

2) verbs of communicated message (11) such as 'สอน' [sว̌on] or 'teach,' 'รายงาน' [raayyaan] or 'report,' and 'แจ้ง' [cæ̂æฺ] or 'inform.'

\begin{tabular}{llll} 
สมชาย & สอน & เลข & ฉัน \\
Sǒmchaay & sǒon & lêek & chăn \\
Somchaay & teach & math & I \\
\multicolumn{2}{l}{ 'Somchaay taught me math.' }
\end{tabular}

\section{DATIVE STRUCTURES}

Basically, a direct object is placed after a verb, whereas an indirect object or a dative object is placed after the preposition to. The sentence (12) illustrates this characteristic.

a. John gave [Do a new laptop] to [ı Mary].

The objects of the dative structure involve semantic roles and an action of transference between the recipient and the patient. The indirect object is the recipient of an action, whereas the direct object is the patient. The sentence (12) shows that an object (a patient-a new laptop) was conveyed to Mary (a recipient- a person). Overall, the differences and similarities between English and Thai double object constructions are summarized in Table 2 (Timyam, 2015, p. 151).

TABLE 2. English-Thai ditransitive and dative structures

\begin{tabular}{ccc}
\hline Structure & English & Thai \\
\hline Ditransitive & Verb+Recipient+Patient & Verb+Patient+Recipient \\
Dative & Verb+Patient+to Recipient & Verb+Patient+to Recipient \\
\hline
\end{tabular}

Compared to English dative structures, Thai has several prepositional markers in dative sentences (e.g. แก่ and กับ). The uses of these two prepositions depend on verbs which are illustrated in the sentences below.

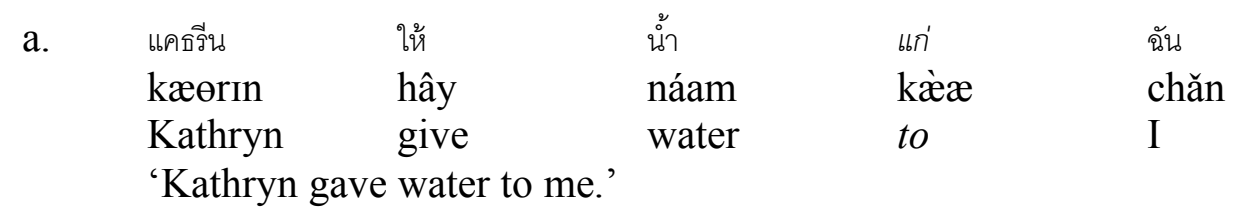


b.

$\begin{array}{lll}\text { ฉัน } & \text { บริจาค } & \text { เงิน } \\ \text { chăn } & \text { boorícàak } & \text { yən } \\ \text { I } & \text { donate } & \text { money } \\ \text { 'I donated money to the hospital.' }\end{array}$

\author{
กับ โรงพยาบาล \\ kàp roon-pháyaabaan \\ to hospital
}

(Adapted from Timyam, 2015)

\section{RELATED STUDIES}

Aside from the theories of crosslinguistic variation stated earlier, several educators have discussed about how to enhance language teachers with the content knowledge of linguistics and integrated areas of English writing (Nguyen, 2019; Richard, 1990; Xie \& Yuan, 2020). Along this line, many studies have been conducted related to L1 and L2 transfer in EFL students' English writing (Chanwaiwit, 2018; Nguyen, 2019; Petchprasert, 2013; Petchprasert, 2021) and the crosslinguistic manifestations of the event schema argument in double object construction (Haspelmath, 2015; Jiang \& Huang 2015; Levin, 2008; Pongyoo, 2018).

For example, Nguyen's (2019) study shows the relatively high percent of neutral and negative attitudes towards English writing pedagogy, determining the challenges the participants faced. These participants were Thai pre-service teachers studying in an essay writing course. Since they had never taken English writing as a subject at their secondary schools (Nguyen, 2018), these pre-service teachers found teaching English writing was a challenge to them. Advocated by the results from the interviews, the participants could not clearly understand and see how to manage their teaching sequences, activities or select techniques to teach a particular writing task. Nguyen states further that English teacher preparation program at a university should accommodate prospective teachers to acquire sufficient knowledge and language skills before studying in a writing course.

Regarding writing experiences, researchers have investigated pre-service teachers and EFL students' writing performances. For example, Atay and Kurt (2006) found that the levels of writing anxiety were associated with inadequate past experience with writing. Xie and Yuan (2020) found a large proportion of teacher students at an advanced level of English proficiency reported high or moderate levels of writing anxiety. They also suggest that it is necessary to equip pre-service teachers with effective techniques in English writing.

Kampookaew (2020) found that her Thai EFL participants made grammatical errors, determining the quality of their writing. The participants were 29 second-year students enrolled in an EAP writing class at a public university in Thailand. According to the findings of the study, grammatical accuracy is a key element of good writing. Regarding academic writing skills, Çelik's (2020) study shows that five doctoral-level students in English Language and Literature at a university in Turkey expressed specific concerns over understanding of standards for academic writing and English grammar.

In terms of the crosslinguistic manifestations of the two event schemata, they are in line with a study carried out by Haspelmath (2015). His study identifies three arguments (an agent, a theme, and a recipient), which express an event of possessive transfer through words, such as give and lend or an event of cognitive transfer through words, such as tell and show. This crosslinguistic study expresses that a ditransitive verb such as give shows a stronger tendency for neutral alignment than those with a more spatial meanings, such as bring and send.

Pongyoo's (2018) study investigated how Thai learners used the five dative verbs: give, send, bring, lend, and hand in a translation task. The participants were asked to translate ten Thai dative sentences into English. The results show that the participants used prepositional dative (PD) more frequently than double object (DO) across the two groups of students. Likewise, the results of the second survey show that PD was used more often than DO in the translation task across all proficiency groups. 
In accordance with the picture word prompts in the present study, Datchuk (2016) used picture prompts to measure the effects of a writing intervention to identify combined sentence construction. Likewise, Jiang and Huang's (2015) study aimed to investigate the role of structural priming in Chinese EFL learners' acquisition of double object construction (DOC). The participants were 60 learners from three intact English classrooms at a college. They found that the two treatment groups showed an increase in direct object production in picture description tasks.

As earlier discussed, the literature review and the findings from previous research show that pre-service teachers are required to have sufficient English writing skills, writing experiences, and knowledge of the variation of crosslinguistic sentence structures. Then, it is worth stressing on the participants' abilities to spontaneously apply their L1 and L2 knowledge of two-event schemata in their DOC writings. The present study then focused on the three research objectives as follows:

1. to investigate the associations of verbs with certain event schemata;

2. to investigate the syntactic and semantic realizations available to the ditransitive and dative sentence structures across languages; and

3. to examine the associations between the parallel structures of the sentences across languages.

\section{METHOD}

\section{PARTICIPANTS}

There was participant attrition, with 76 beginning the survey, and 70 completing it. These Thai participants were pre-service teachers majoring in English at a university in Thailand. These participants have studied English as a compulsory subject for over ten years.

\section{RESEARCH TOOL AND DATA COLLECTION}

In the present study, the data were collected through an online questionnaire and an online test on an electronic platform to investigate the two event schemata in English and Thai sentences as well as the associations between the parallel structures of those sentences. The participants and their responses were kept anonymous. An online survey was administered through Google Forms, beginning in February, 2020, and concluding in August, 2020. The call to participate was initially posted on Facebook page of the English Major Division under the Department of Curriculum and Instruction at the targeted university.

\section{DEMOGRAPHIC AND OTHER BACKGROUND INFORMATION}

Interested participants were directed to the consent form which was the first segment of the online survey and only people who agreed to participate were directed to the questions. The participants were asked to answer both close-ended questions and open-ended questions about demographic information, educational background, and experiences in teaching and writing in English. The quantitative survey data were analysed using descriptive statistics. 


\section{PICTURE WORD PROMPTS}

According to Singh and Solman (1990) state that pictures can be used as stimulus prompts which may be advantageous as the participants in their study acquired words more quickly when the words were paired with pictures rather than presented alone, suggesting that some individuals may benefit from pair words with pictures presented. Likewise, Datchuk (2016), a picture-word prompt is a page of pictures with two to three relevant words accompanying each picture and lines for writing about the pictures. Picture prompts may enhance writing skill when they are combined with methods as the pictures are a more salient stimulus than words alone.

As for the purposes of the present study, the researcher designed an online questionnaire and an online test on the same platform. Through guided practice, the participants were asked to identify their uses of ditransitive or dative sentence structures by constructing sentences for picture-word prompts and translating assigned sentences from English into Thai and vice versa. The picture-word prompts were used to measure the effects of a writing intervention with the goals of identifying combined sentence constructions. The prompts were designed to investigate English and Thai sentence constructions containing one verb in English such as 'give' and the other verb in Thai such as 'ให้' [hây] meaning 'give.' Each test item consisted of one picture, representing the actions associated with the ditransitive or dative structures.

\section{SENTENCE TRANSLATION}

This section of the online written test consisted of three sentences for the purpose of translation into English, as in (17 a-b) and into Thai, as in (25). Specifically, the English and Thai verbs provided in the test were based on the uses of the ditransitive or dative structures and the two event schemata. The test words were clarified in the online test with illustrations.

As for the quality of the test, the validity of the drawings and the overall test were assessed by three experts who are lecturers and researchers at a tertiary level with more than ten years of experience in Teaching English as a Foreign Language (TEFL). Overall reliability of the test was .84, which is acceptable for a teacher made test (Wells \& Wollack, 2003).

The qualitative data gathered from the online written test were analysed based on the theoretical framework on the crosslinguistic manifestation of the event schema-argument realization in English and Thai sentences, and the associations between the parallel structures of the ditransitive and dative constructions across the languages.

\section{RESULTS AND DISCUSSIONS}

Only data that met all underlying assumptions necessary for conducting a research design were analysed. The participants were assigned to the treatment by strictly adhering to the assignments concerning the two event schemata in the sentences and the relationships between the parallel structures of the ditransitive and dative constructions.

\section{THE PARTICIPANTS’ BACKGROUND INFORMATION}

The following tables show the 70 participants' background information and their experiences in learning and using English. 
AGE RANGES

TABLE 3. Age ranges of the participants

\begin{tabular}{ccc}
\hline $\begin{array}{c}\text { Age Range } \\
\text { (years) }\end{array}$ & $\begin{array}{c}\text { Frequency } \\
(n=70)\end{array}$ & $\begin{array}{c}\text { Percent } \\
(\%)\end{array}$ \\
\hline Under 18 & 0 & 0.00 \\
$18-25$ & 42 & 60.00 \\
$26-30$ & 7 & 10.00 \\
$30-35$ & 8 & 11.43 \\
$36-40$ & 7 & 10.00 \\
Over 40 & 6 & 8.57 \\
\hline Total & 70 & 100.00 \\
\hline
\end{tabular}

Sixty percent of the participants' ages ranged from $18-25$ years $(n=42)$, followed by the group of 26-40 years of age $(n=22,31.43 \%)$.

HIGHEST EDUCATIONAL ATTAINMENT

TABLE 4. Participants' highest educational attainment

\begin{tabular}{ccc}
\hline Educational Level & $\begin{array}{c}\text { Frequency } \\
(n=70)\end{array}$ & $\begin{array}{c}\text { Percent } \\
(\%)\end{array}$ \\
\hline High school graduate or equivalent & 24 & 34.29 \\
Bachelor's degree & 33 & 47.14 \\
Master's degree & 11 & 15.71 \\
Doctoral degree & 2 & 2.86 \\
\hline Total & 70 & 100.00 \\
\hline
\end{tabular}

According the data shown in Table 4, a majority of the participants ( $n=46,65.71 \%)$ held a bachelor's degree or higher, compared to 24 participants $(34.29 \%)$ who had a high school diploma. From this result, a larger number of the participants have already received one or more baccalaureate degrees and they are enrolled in English major to earn another degree at the targeted university.

OCCUPATIONS

TABLE 5. Participants' occupations

\begin{tabular}{|c|c|c|}
\hline Career & $\begin{array}{l}\text { Frequency } \\
(n=70)\end{array}$ & $\begin{array}{l}\text { Percent } \\
(\%)\end{array}$ \\
\hline students & 56 & 80.00 \\
\hline $\begin{array}{l}\text { government officials /state enterprise } \\
\text { employees }\end{array}$ & 10 & 14.29 \\
\hline freelancers & 4 & 5.71 \\
\hline Total & 70 & 100.00 \\
\hline
\end{tabular}

Of the 70 participants, a majority of the participants $(n=56,80 \%)$ reported that they were students, whereas the rest of them $(n=14,20 \%)$ reported working in government and business sectors.

\section{THE PURPOSES OF WRITING IN ENGLISH}

TABLE 6. The purposes of writing in English reported by the participants

\begin{tabular}{ccc}
\hline Purpose & Frequency & Percent \\
$(n=70)$ & $(\%)$ \\
\hline Communication (e.g. E-mail, social media) & 21 & 30.00 \\
Academic reports/assignments & 42 & 60.00 \\
Business reports & 5 & 7.14 \\
Other (e.g. diary, teaching) & 2 & 2.86 \\
\hline Total & 70 & 100.00 \\
\hline
\end{tabular}


Sixty percent $(n=42)$ of the participants reported that their main purposes of English writing was to write academic reports or to complete their school assignments, whereas the second most selected purpose was to communicate through E-mail or social media threads ( $n$ $=21,30 \%$ ).

KNOWLEDGE OF DITRANSITIVE AND DATIVE SENTENCE CONSTRUCTIONS

TABLE 7. Participants' knowledge of ditransitive and dative sentence constructions

\begin{tabular}{ccc}
\hline $\begin{array}{c}\text { Knowledge of Ditransitive and } \\
\text { Dative Construction }\end{array}$ & $\begin{array}{c}\text { Frequency } \\
(n=70)\end{array}$ & $\begin{array}{c}\text { Percent } \\
(\%)\end{array}$ \\
\hline Know & 23 & 32.86 \\
Don't know & 26 & 37.14 \\
Not sure & 21 & 30.00 \\
\hline Total & 70 & 100.00 \\
\hline
\end{tabular}

Approximately 30 percent of the participants reported that they gained knowledge of ditransitive and dative sentence structures through classes or other learning resources $(n=23)$, other did not know the syntactic structures $(n=26,37.14 \%)$, the other were uncertain if they knew the double object construction $(n=21,30 \%)$.

\section{THE PICTURE-WORD PROMPTS}

The words assigned for the part of picture prompts were apple and give for English writing, whereas 'ของขวัญ' [khว̌วy-khwăn] or 'a gift' and 'ให้' [hây] or 'give' were provided in Thai writing. Then, the participants were asked to look at the pictures and used the words provided to construct sentences and type sentences in the lines provided on the online platform. Through the use of the picture-word prompts, the findings agree with that of Datchuk (2016) and Jiang and Huang (2015) who found that the participants could construct DOC sentences with the restricted range of words.

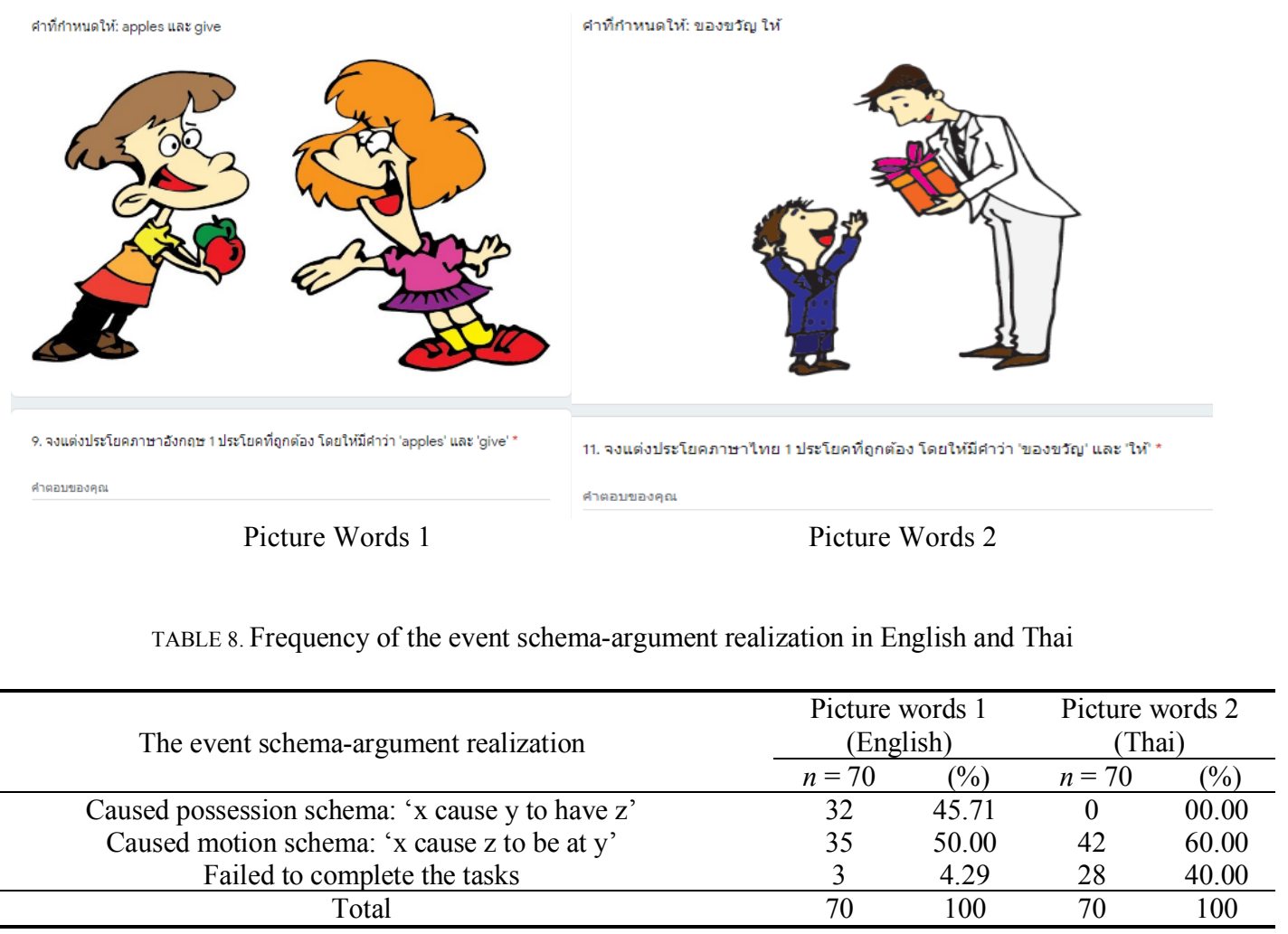


A majority of the 70 participants tend to use the caused motion schema in their sentences across all prompts. Besides, there was no participants used the caused possession schema in their Thai sentences.

\section{THE PICTURE-WORD PROMPTS: ENGLISH AND THAI DITRANSITIVES}

In English, the caused motion schema in English sentences $(n=35,50 \%)$ and the caused possession schema $(n=32,45.71 \%)$ were used to construct sentences respectively (see Table 8).

In Thai, 60 percent of the participants $(n=42)$ tend to use the caused motion schema rather than the caused possession schema $(n=0)$. To explain this point of the sentence constructions between English and Thai ditransitives, there have been different proposals to account for Thai syntax of ditransitive sentence constructions.

Pylkkänen (2008) stated that ditransitive structures in Thai and English are different as a Thai ditransitive structure is not a basic one. By considering this ditransitive structure in Thai with the translated sentence in English, these sentences are grammatically correct, but the Thai sentence sounds awkward and ungrammatical for Thai syntax and semantics, as in (14).

$\begin{array}{llll}\text { พ่อ } & \text { ให้ } & \text { ลูกชาย } & \text { ของขวัญ } \\ \text { phôo } & \text { hây } & \text { lûukchay } & \text { khǒวy-khwăn } \\ \text { Father } & \text { give } & \text { son } & \text { a gift }\end{array}$

'Father gave son a gift.'

A different approach to the ditransitive structure in Thai would be the proposal of Timyam (2015), stating about the omission of prepositions, such as แก่ [kæ̀æ] and กับ [kàp] that are semantically equivalent to the preposition to in English. Those prepositions are commonly counted for both English and Thai dative structures. As stated earlier in Table 2, the verbs and the recipient or beneficiary of the action can be summarized as Verb+Patient+Recipient. The sentence (15) is considered as a Thai ditransitive structure written by a participant.

$\begin{array}{llll}\text { พ่อ } & \text { ให้ } & \text { ของขวัญ } & \text { เด็ก } \\ \text { phôว } & \text { hây } & \text { khǒวy-khwăn } & \text { dèk } \\ \begin{array}{l}\text { Father } \\ \text { 'Father gave a child a gift.' }\end{array} & \text { give } & \text { child } \\ \end{array}$

The sentence (15) demonstrates the patient 'ของขวัญ' [khว̌oy-khwăn] or 'a gift' precedes the recipient 'เด็ก' [dèk] or 'a child.' This is the case by omitting prepositions, such as 'แก่' [kæ̀æ] and 'กับ' [kàp] which trigger different double object constructions between English and Thai.

In Thai, the recipient is normally marked by hây or give (Thepkanjana \& Uehara 2008) which predicates a direct benefactive relationship between the internal argument of 'give' which is 'ของขวัญ' [khว̌วy-khwăn] or 'a gift,' and the recipient who is 'เด็ก' [dèk] or 'a child.'

\section{THE PICTURE-WORD PROMPTS: ENGLISH AND THAI DATIVES}

According to the expected pattern of data in this study, the give-type verbs in English are associated with the caused possession schema and caused motion schema where the recipient can be situated in two main positions-with or without $t o$.

According to Table 8, half of the participants $(n=35,50 \%)$ wrote their English sentences using the caused motion schema with the preposition to as a dative marker. The verb give in English as in Thai, was significantly associated with the caused motion schema. 
Besides, in English the verb give expresses its recipient using the dative case like 'to.' The findings partially agree with that of Pongyoo (2018), Haspelmath (2015), and Levin (2008) who found a strong tendency of caused motion schema with the use of the dative case 'to.'

Due to its association with the caused motion schema, the verb give would be expected to show a wider range of argument realization options. A sample sentence (16) written by a participant illustrating this characteristic.

$\begin{array}{lllll}\text { พ่อ } & \text { ให้ } & \text { ของขวัญ } & \text { แก่ } & \text { ลูกชาย } \\ \text { phôs } & \text { hây } & \text { khǒวy-khwăn } & \text { kæ̇æ } & \text { lûukchay } \\ \text { Father give } & \text { a gift } & \text { to } & \text { son } \\ \text { 'Father gave a gift to } \text { son.' } & & \end{array}$

In Thai, the verb 'give' [hây] is also associated with the caused motion schema with several dative markers including the prepositions, such as แก่ [kæææ] and กับ [kàp] that are equivalent to the preposition to in English. The following sentences (a-b) reiterate this characteristic.

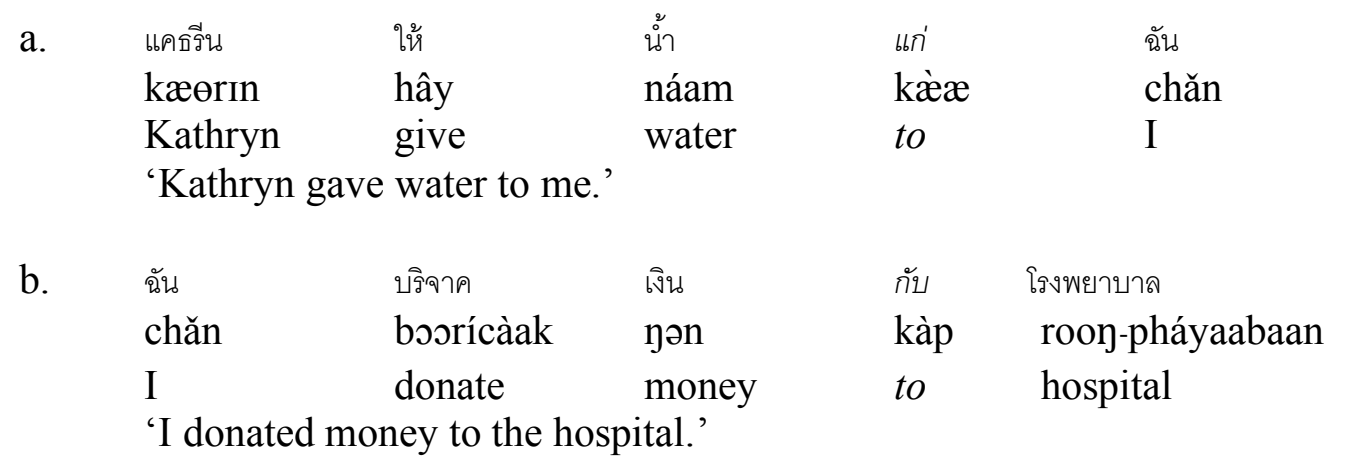

(Adapted from Timyam, 2015)

Of the 70 participants, approximately 40 percent $(n=26)$ tend to use 'แก่' [kæ̀æ] as a dative marker, whereas about 23 percent $(n=16)$ used 'กับ' [kàp] in their sentences.

According to the results, the verb 'ให้' [hây] or 'give' and 'บริจาค' [boorícàak] or 'donate' can also be used with dative prepositions, such as แก่ [kæ̀æ] or กับ [kàp]. Speakers of Thai tend to use the combinations of ให้แก่ [hây- kæ̀æ] and ให้กับ [hây- kàp] considering them as dative markers. Specifically, ให้กับ [hây- kàp] is not grammatically correct, but is widely used amongst Thai people (Wiwatsorn, 1998) and even often found in verbal and written Senate's hearings and meetings (Office of Royal Society, n.d.). Besides, Thai writers commonly choose either แก่ [kæ̀æ] or กับ [kàp] depending on the verbs that are used in sentences. Some verbs tend to be used with แก่ [kæ̇æ], whereas others occur with กับ [kàp] or they are often used interchangeably.

In conclusion, the findings agree with that of Levin (2008) and Timyam (2015) who found that the ditransitive and dative structures in English are generally marked by different orders of two objects and the dative preposition. The caused possession schema may be realized by both the double object and to variant, while the caused motion schema is realized only by the preposition to. Those two structures in Thai are simply associated with the absence or presence of the dative preposition.

\section{SENTENCE TRANSLATION}

The following sentences as in (17a-b) were assigned purposely for the participants to translate from Thai into English. It was expected that the participants would generate English sentence structures from L1 or L2 syntactical background knowledge. The results of the study are 
demonstrated in Table 9. The sentence as in (25) was assigned for the participants to translate from English into Thai.

TABLE 9. Frequency of the event schema-argument realization in translations from Thai into English

\begin{tabular}{ccccc}
\hline \multirow{2}{*}{ The event schema-argument realization } & \multicolumn{2}{c}{$\begin{array}{c}\text { Sentence 17a } \\
\text { (Thai-English) }\end{array}$} & \multicolumn{2}{c}{$\begin{array}{c}\text { Sentence 17b } \\
\text { (Thai-English) }\end{array}$} \\
\cline { 2 - 5 } & $n=70$ & $(\%)$ & $n=70$ & $(\%)$ \\
\hline Caused possession schema: 'x cause y to have z' & 15 & 21.43 & 10 & 14.29 \\
Caused motion schema: 'x cause z to be at y' & 39 & 55.71 & 45 & 64.29 \\
Failed to complete the tasks & 16 & 22.86 & 15 & 21.42 \\
\hline Total & 70 & 100 & 70 & 100 \\
\hline
\end{tabular}

TRANSLATIONS FROM THAI INTO ENGLISH

$\begin{array}{lllll}\text { a. จอห์น } & \text { โยน } & \text { ขนมปัง } & \text { ให้ } & \text { ปลา } \\ \text { jan } & \text { yoon } & \text { khànǒm-pay } & \text { hây } & \text { plaa } \\ \text { John } & \text { throw } & \text { bread } & \text { to } & \text { fish } \\ \text { 'John threw bread to fish, } & & \end{array}$

Ditransitive. The quantitative data show that approximately 20 percent $(n=15)$ of the participants used the caused possession schema in which the verb feed $(n=9,12.86 \%)$ was found slightly higher than the assigned verb throw $(n=6,8.57 \%)$. The findings demonstrated that the participants tend to focus on meanings rather than the verb assigned in the test, as in (18). This could be that the verb throw naturally represents an association as it lexicalizes notions of instrument and manner. The results also entailed the crosslinguistic perspectives such as the variation of semantics between English and Thai. Therefore, it is assumed that the participants focused on their L1 semantics and the authentic Thai language use in their daily lives as demonstrated by replacing the assigned verb throw with the verb feed. Besides, the participants expressed their understanding of doing the action throwing was to feed the fish as in (19), representing semantic awareness. The sentences (18-19) written by different individuals illustrating the characteristics mentioned earlier.

(18) John threw the fish some bread.

(19) John feed the fish some bread.

Dative. Interestingly, a large proportion of the participants used the assigned verb throw ( $n=$ $36,51.43 \%$ ) in the dative sentences more frequently than those in the ditransitive ones. This finding shows a strong preference for the dative case, which indicates caused motion schema. The result is a preference for a sentence written by a participant as in (20) over the one as in (18).

\section{John throws bread to fish.}

Of the 36 participants, the verb give was used to replace the assigned verb throw $(n=3,4.28 \%)$. Even though it was a relatively small number of the participants, it can be assumed that Thai writers might perceive that the verb give was assumedly conveyed more direct meaning to the action than that of English. The participants may semantically realize a restricted range of arguments. In addition, the verb throw has both caused motion and caused possession schemata showing that the association between these two event schemata and their semantics in Thai language is complex and elaborate. 
The verb donate can appear in the oblique dative construction without double object counterpart (Larson, 1988), as in (21).

(21) a. John donated charity money.

b. John donated money to charity.

(Larson, 1988, pp. 369-371)

The sentence (21a-b) shows that the suppression of the to variant might lead to doubt the derivational connection between oblique and double object forms. Since those sentences do not express the possession from a source and transference of possession to the spatial goal [charity], the sentence structure can be dative shift which is presented in the following sentences $(22 a-b)$.

(22) a. I gave away charity money. / gave charity away money.

b. I gave away money to charity.

(Larson, 1988)

In line with the purposes of the study, the verb donate assigned for the participants to use in their writing was in the double object construction to avoid the ambiguity and to distinctively point to the ditransitive and dative sentence structures or the dative shift as mentioned earlier. The assigned sentence for the participants to translate from Thai into English is reiterated from $(17 b)$.

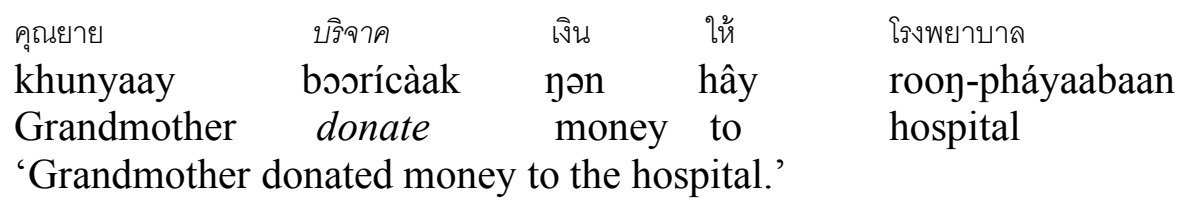

Ditransitive. As shown in Table 9, a relatively small number of the participants $(n=10$, $14.29 \%$ ) wrote their sentences in ditransitive sentence structures, conveying a meaning of transference which is associated with inherent acts of giving with the spatial goal (Timyam, 2015). The following sentence (23) written by a participant illustrating this characteristic.

A grandmother donates a hospital some money.

Regarding the L1 background knowledge and semantic realm, the word hospital can be implied to a place, an administrative board of hospital, or a group of people working at hospital, as in (23).

Dative. With the account of ditransitive sentence structures shown above, I now return to another double object construction as represented in dative sentence structures. Of the 70 participants, over 60 percent $(n=45)$ used the caused motion schema to animate the active sequences of translated sentences. Since the verb donate indicates either a recipient or a spatial goal, this verb shows a single realization of its arguments and does not show a dative alternation. The sentence (24) written by a participant demonstrates that only the to variant is available and syntactically accurate, suggesting that the caused motion schema is solely presented.

(24) My grandmother donated some money to the hospital. 
As in (24), this argument demonstrates the way Thai writers attempted to elaborate their L2 sentences with background in L1 writing. For this reason, English and Thai languages available for the two schemata revolve around the expressions of the recipient and spatial goal.

Besides, a majority of the participants tend to use the dative structure rather than the ditransitive structure across all writing assignments. The caused motion schema was perceived to be significantly used in both English and Thai.

\section{TRANSLATION FROM ENGLISH INTO THAI}

One way in which analyses of the double object construction was taken to be proved was the way in which the participants were asked to translate an English wh-phrase in ditransitive structure, as in (25). This was carried out to see whether the participants continued using the dative structure in their Thai translated sentences.

$$
\text { What did John send you? }
$$

The results of the analyses show that a large proportion of the participants used the caused motion schema $(n=58,82.86 \%)$, whereas twelve participants $(18 \%)$ failed to complete this writing task. The following sample sentences written by participants illustrated this characteristic.

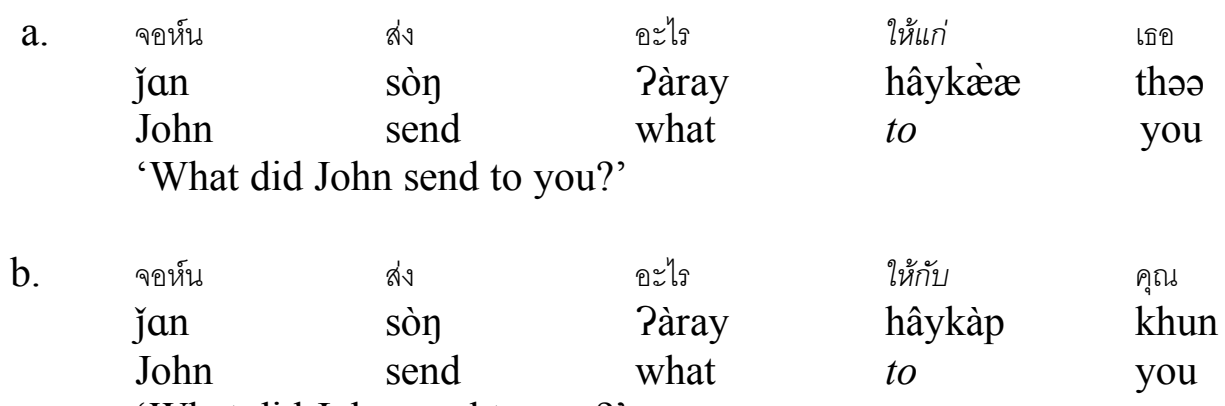

Of the 58 participants, it was found that 52 participants used the verb 'ให้' [hây] or 'give' as a dative marker which is commonly used in Thai sentences. Specifically, the verb ให้ in Thai sentences in the translated version does not provide the meaning of give, but a preposition for dative structure, as in (26). Besides, six participants of the 58 participants used ให้แก่ [hây- kæ̀æ] and ให้กับ [hây- kàp], as in (27a-b), which is a combination of dative markers (Iwasaki \& Ingkaphirom, 2005). This could be that the participants used the verb 'ให้' [hây] or 'give' as a verb or a preposition depending on syntactic and semantic properties with the realization of the recipient and the goal in the caused motion schema.

In summary, the caused motion schema plays a significant role in a sentence construction as performed by a majority of the participants. The reason, as already stated, is that the syntactic realizations of the caused motion schema depend on the syntactic and semantic properties of English and Thai languages. As these properties may vary, the actual demonstrations of the schemata may likely to be associated with the realization of the recipient and the spatial goal in the dative sentence structures. 


\section{CONCLUSIONS AND FUTURE RESEARCH IMPLICATIONS}

This study examined the possible associations of verbs with the two event schemata, syntactic and semantic realizations available to the double object construction (DOC), and the associations between the parallel structures of the sentences in English and Thai languages.

Overall, the findings of the present study show that the two event schemata (the caused motion and the caused possession) were similar or different due to the syntactic and semantic resources available to the targeted languages. Most sentences with the verb give in English were associated with the caused possession schema and caused motion schema where the recipient could be situated in two main positions with/without 'to.' The verbs like throw and donate were significantly correlated with caused motion schema to animate the active sequences. These verbs also indicate either a recipient or a spatial goal with dative markers like to in English, whereas dative prepositions, such as แก่ [kæ̇æ] and กับ [kàp] were found in Thai sentences.

With respect to the second purpose of the study, the possibly syntactic and semantic realizations available to the event schemata were found different in the resources that languages bring to the expression of the ditransitive and dative sentence constructions. English might seem comparable to Thai in terms of the positions of the objects or the uses of dative markers like to in English and แก่ [kæ̀æ] or กับ [kàp] in Thai.

Furthermore, the crosslinguistic similarities in sentence structures were found associated across the languages, except the ditransitive structures in Thai with the translated sentences in English that were different. For example, by considering the double object constructions in English and Thai, the ditransitive structure in Thai with the English translated sentences were found grammatically correct; however, the Thai sentences sound awkward and ungrammatical for Thai syntax and semantics. Overall, a majority of the participants tend to use the dative sentence structures that were associated with the caused motion schema across all writing tasks (the picture word prompts and the sentence translation) provided on the online writing platform. The analyses show further findings extended earlier studies by expressing the sematic awareness and the word selection in L1 and L2 writings.

The limitations of this study should also be acknowledged and addressed in future studies. First, the participants in this study were limited to pre-service teachers at a university. This limitation makes the findings less generalizable to other contexts. Future studies may recruit a larger number of participants from other universities to determine if the same patterns exist in DOC texts. Second, future studies might continue in the field of ditransitive and dative sentence structures focusing on participants at different levels of English proficiency.

The findings have implications for L2 writing research and instruction. In research, EFL educators may investigate individual differences and other related variables, such as language aptitude, motivation, and writing experience in L2 writing (Atay \& Kurt, 2006; Nguyen, 2019). In writing pedagogy, pre-service teachers should have sufficient knowledge with hands-on experience in L1 and L2 writing to fulfill their professional goals.

\section{ACKNOWLEDGMENTS}

I would like to sincerely thank Dr. Rujira Bumrungkarn for insightful guidance. Most importantly, I would like to thank the participants, without your support I could not have done this study. Any opinions, findings, and conclusions or recommendations expressed in this paper are those of the author and do not reflect the views of the university. 


\section{REFERENCES}

Atay, D. \& Kurt, G. (2006). Prospective teachers and L2 writing anxiety. Asian EFL Journal, 8(4), 100-118.

Chanwaiwit, P. (2018). Using effective feedback to improve professionalism as an English student teacher. The New English Teacher, 12(2), 1-4.

Çelik, S. (2020). Building critical academic writing skills: The impact of instructor feedback on Turkish ELT graduate students. TESL-EJ: Teaching English as a Second or Foreign Language, 24(3), 1-18.

Datchuk, S.M. (2016). Writing simple sentences and descriptive paragraphs: Effects of an intervention on adolescents with writing difficulties. Journal of Behavioral Education, 25, 166-188.

Goldberg, A. E. (1995). A Construction Grammar approach to argument structure. Chicago and London: University of Chicago Press.

Haspelmath, M. (2015). Ditransitive constructions in the world's languages, Annual Review of Linguistics, 1(1), 19-41. https://doi.org/10.1146/annurev-linguist-030514-125204

Hovav, M.R. \& Levin, B. (2008). The English dative alternation: The case for verb sensitivity. Journal of Linguistics, 44, 129-167.

Iwasaki, S., \& Ingkaphirom, P. (2005). A Reference Grammar of Thai. Cambridge \& New York: Cambridge University Press.

Jackendoff, R. S. (1990). On Larson's treatment of the double object construction. Linguistic Inquiry, 21(3), 427456.

Jiang, L., \& Huang, K. (2015). The efficacy of structural priming on the acquisition of double object construction by Chinese EFL learners. Higher Education Studies, 5(5), 38-49.

Kampookaew, P. (2020). An analysis of grammatical errors made by Thai EFL university students in an EAP writing class: issues and recommendations. rEFLections, 27(2), 246-273.

Larson, R. (1988). On the Double Object Construction. Linguistic Inquiry, 19(3), 335-391. http://www.jstor.org/stable/25164901

Levin, B. (2008). Dative verbs: A crosslinguistic perspective. Lingvistica Investigationes, 31(2), 285-312.

Nguyen, T. T. L. (2018). Reflections on modified genre-based instructions to teach essay writing to Thai university students. The Asian EFL Journal, 20(9.1), 148-174.

Nguyen, T. T. L. (2019). Reflective teaching in an EFL writing instruction course for Thai pre-service teachers. The Journal of Asia TEFL, 16(2), 561-575.

Office of Royal Society (n.d.). Knowledges. http://www.royin.go.th/?knowledges

O'Grady, W. (1998). The syntax of idioms. Natural Language \& Linguistic Theory, 16, 279-312.

Petchprasert, A. (2013). A study of cohesive markers used in 11 and 12 essay writing: translation versus direct composition. 3L: The Southeast Asian Journal of English Language Studies ${ }^{\circledR}, 19(1), 19-33$.

Petchprasert, A. (2021). Utilizing an automated tool analysis to evaluate EFL students' writing performances. Asian- Pacific Journal of Second and Foreign Language Education,6(1), 1-16. https://doi.org/10.1186/s40862- 020-00107-w

Pongyoo, T. (2018). The acquisition of dative constructions by Thai learners of English [Unpublished doctoral dissertation]. Thammasat University.

Pylkkänen, L. (2008). Introducing arguments. Cambridge, MA: MIT Press.

Richards, J.C. (1990). The dilemma of teacher education in second language teaching, in Richards, JC \& Nunan, D. (Eds.), Second Language Teacher Education. USA: Cambridge University Press.

Singh, N., \& Solman, R. (1990). A stimulus control analysis of the picture-word problem in children who are mentally retarded: The blocking effect. Journal of Applied Behavior Analysis, 23, 525-532.

Thepkanjana, K., \& Uehara, S. (2008). The verb of giving in Thai and Mandarin Chinese as a case study of polysemy: A comparative study. Language Sciences, 30(6), 621-651.

Timyam, N., \& Bergen, B.K. (2010). A contrastive study of the caused-motion and ditransitive constructions. In H.C.Boas (Ed.), English and Thai: Semantic and pragmatic constraints. Contrastive Studies in Construction Grammar (pp. 137-168). Amsterdam/Philadelphia: John Implication for future research.

Timyam, N. (2015). A comparative study of English and Thai: An introduction. Kasetsart University Press. Bangkok.

Wells, C. S., \& Wallack, J. A. (2003). An Instructor's Guide to Understanding Test Reliability. Wisconsin: Testing and Evaluation Services, University of Wisconsin.

Wiwatsorn, W. (1998). Moonbotbanpakit: the use of kab, kae, tae, and taw. Journal of Letters, 27(2), 81-90.

Xie, Q. \& Yuan, J. (2020). English writing anxiety and preservice teacher' written corrective feedback. Language Education \& Assessment, 3(2), 58-84. https://doi.org/10.29140/lea.v3n2.357 